\title{
HOODED MERGANSER BROOD AT DELTA MARSH
}

RICHARD M. KAMINSKI, Delta Waterfowl Research Station, Delta, Manitoba RTN 3A1

The primary breeding range in Canada of the Hooded Merganser includes southern Ontario and Quebec. ${ }^{1}$ Although the species' Canadian range extends intermittently from Nova Scotia northwestward to southeast Alaska, ${ }^{2}$ few records of breeding originate from the Prairie Provinces. Breeding Hooded Mergansers are generally found in forested regions, commonly riverine habitats, because the species is a cavity nester. ${ }^{4}$ This note documents the first known sighting of a Hooded Merganser brood on the Delta Marsh within the true prairie of southcentral Manitoba.

On July 24, 1976 (1330), a female Hooded Merganser and her brood of three Class II ducklings were sighted by Patrick Godin (University of Guelph, Ontario) and myself in a man-made canal approximately $3 \mathrm{~km}$ east of the Delta Waterfowl Research Station headquarters. We observed the group swimming at a distance of about $10 \mathrm{~m}$ for approximately $20 \mathrm{sec}$. before we startled them, and they went into cover. They were not seen again.

No broods of Hooded Mergansers have been reported, among 2905 brood sightings made during surveys conducted on the Delta Marsh in July 1950, 1965-1966, and 1975-1976 (R. E. Jones pers. comm.). Although Thompson ${ }^{5}$ documents observations of Hooded Mergansers as summer residents near Portage la Prairie, Manitoba, and Hochbaum ${ }^{3}$ reports that the species occurs only as a spring transient, this observation reveals that the species can nest within the sparsely forested Delta Marsh. The breeding of this species along with the recent occurrence of other cavity nesting anatids (i.e. Wood Duck and Common Goldeneye), may be related to the availability of nest boxes near the Delta station. Hooded Mergansers readily nest in artificial structures; ${ }^{1}$ however, the nearest nest box to the observation site was over $3 \mathrm{~km}$ away. Inasmuch as the brood was sighted less than $1 \mathrm{~km}$ from a forested ridge, one cannot discount the possibility that the female nested in a tree cavity. The species has also been known to nest in badger holes, under rocks in ravines and a sandstone cavity. ${ }^{4}$

The author is grateful to B. D. J. Batt for editing the note.

1BELLROSE, F. C. 1976. Ducks, geese and swans of North America. Stackpole Books, Harrisburg. 544 pp.

${ }^{2}$ GODFREY, W. E. 1966. The birds of Canada. Queen's Printer, Ottawa. $428 \mathrm{pp}$.

${ }^{3} \mathrm{HOCHBAUM}, \mathrm{H}$. A. 1944 . The Canvasback on a prairie marsh. Stackpole Books, Harrisburg. 207 pp.

${ }^{4}$ STEWART, R. E. 1975. Breeding birds of North Dakota. Tri-College Center for Environmental Studies, Fargo, N.D. 295 pp.

${ }^{5}$ THOMPSON, E. E. 1891. The birds of Manitoba. Proc. U.S. Natl. Museum. 13:457-643. 